\title{
MICROPROPAGAÇÃO DE Aspidosperma polyneuron (PEROBA-ROSA) A PARTIR DE SEGMENTOS NODAIS DE MUDAS JUVENIS ${ }^{1}$
}

\author{
Luciana Lopes Fortes Ribas², Flávio Zanette ${ }^{3}$, Luiz Kulchetscki e Miguel Pedro Guerra ${ }^{5}$
}

\begin{abstract}
RESUMO - O presente trabalho teve como objetivo o estabelecimento de um protocolo de regeneração in vitro de mudas de Aspidosperma polyneuron (peroba-rosa), a partir de segmentos nodais de material juvenil. Brotações apicais de mudas de dois anos de idade foram desinfestadas com $0,25 \%$ de hipoclorito de sódio ou $0,05 \%$ de cloreto de mercúrio, durante $10 \mathrm{~min}$, visando ao estabelecimento de culturas assépticas. A indução de brotações múltiplas foi realizada em meio de cultura WPM, suplementado com BAP, ZEA ou CIN (2,2$8,8 \mu \mathrm{M})$, no cultivo inicial e nos dois subcultivos subseqüentes. Para indução de brotações alongadas foram testadas as combinações de fitorreguladores: $2,25 \mu \mathrm{M}$ de BAP, ZEA ou CIN, associadas com 1,25 $\mu \mathrm{M}$ de AIB. A indução de raízes foi avaliada com tratamentos em soluções de AIB (2,5-10 mM), durante 5 ou 15 min. As mudas enraizadas foram transplantadas para casa de vegetação. A desinfestação das brotações apicais foi eficiente com $0,25 \%$ de $\mathrm{NaOCl}$ ou $0,05 \%$ de $\mathrm{HgCl}_{2}$, durante $10 \mathrm{~min}$, obtendo-se 72,89 e $84,10 \%$ de sobrevivência, respectivamente. As maiores taxas médias de regeneração de brotações axilares (4 a 5) foram obtidas em meio de cultura suplementado com ZEA ou BAP $(4,4-8,8 \mu \mathrm{M})$, após o segundo subcultivo. Concentrações mais reduzidas de BAP ou ZEA $(2,25 \mu \mathrm{M})$ e 1,25 $\mu \mathrm{M}$ de AIB proporcionaram, em média, três brotações mais alongadas (1,5$2,5 \mathrm{~cm}$ de comprimento). Tratamentos com soluções de $10 \mathrm{mM}$ de AIB, durante $15 \mathrm{~min}$, foram eficientes na indução de raízes (80\%), e as mudas transplantadas apresentaram taxas de sobrevivência superiores a $90 \%$ em casa de vegetação.
\end{abstract}

Palavras-chave: Cultivo in vitro, propagação vegetativa e conservação.

\section{MICROPROPAGATION OF Aspidosperma polyneuron FROM SINGLE NODE CULTURE OF JUVENILE MATERIAL}

\begin{abstract}
The objective of the present work was to establish a micropropagation protocol of Aspidosperma polyneuron from juvenile material. Apical shoots from two years old seedlings were collected in a greenhouse and sterilised with $\mathrm{NaOCl}$ or $\mathrm{HgCl}_{2}$ to establish aseptic cultures. Multiple shoots induction was evaluated in WPM medium, supplemented with BAP, ZEA or KIN $(2.2-8.8 \mu M)$ in initial culture and two subsequent subcultures. The elongation of shoots was tested with growth regulators combinations: $2.25 \mu M$ of BAP, ZEA or KIN with $1.25 \mu \mathrm{M}$ of IBA. IBA treatments (2.5; 5.0 and $10 \mathrm{mM}$ ) were tested with 5 and 15 minutes to induce roots. Plantlets were planted in a greenhouse. Efficient apical shoots sterilization was achieved with $\mathrm{NaOCl}\left(0,25 \%\right.$ - 10 minutes) or $\mathrm{HgCl}_{2}(0.05 \%$ - 10 minutes $)$; survival rates were $72.89 \%$ and $84,10 \%$, respectively. Apical shoots induced 4-5 axillary buds in WPM culture medium, containing ZEA or BAP (4.4 - 8.8 $\mu M)$ following two subcultures. Reduced concentrations of ZEA or BAP $(2.25 \mu M)$, combined with IBA (1.25) produced elongated shoots. IBA treatment $(10 \mathrm{mM})$ during 15 minutes induced higher rooting percentages (80\%). Plantlets planted in a greenhouse showed higher survival rates (90\%).
\end{abstract}

Keywords: In vitro culture, plant propagation, conservation.

\footnotetext{
${ }^{1}$ Recebido em 27.08.2003 e aceito para publicação em 20.04.2005.

${ }^{2}$ Departamento de Botânica da UFPR. Cx. P. 19031, 81531-970 Curitiba-PR. E-mail: <llfribas@ ufpr.br>.

${ }^{3}$ Departamento de Fitotecnia e Fitossanitarismo da UFPR, Curitiba-PR.

${ }^{4}$ Departamento de Agronomia da UEPG, Ponta Grossa-PR.

${ }^{5}$ Departamento de Fitotecnia/CCA/UFS, Florianópolis-SC.
} 


\section{INTRODUÇÃO}

A Aspidosperma polyneuron Müll. Arg. (perobarosa) é uma espécie nativa da Floresta Estacional Semidecidual, na formação submontana e que corre perigo de extinção pela exploração desordenada para a extração madeireira e a transformação de áreas florestais para o uso na agricultura. Apresenta madeira de excelente qualidade, muito usada na indústria de móveis, em construção civil, construção naval e carpintaria. Hatschbach e Ziller (1995) enquadraram a peroba-rosa como espécie rara da Floresta Estacional Semi-Decidual na lista de plantas ameaçadas de extinção no Estado do Paraná. Essa espécie também se encontra na lista para conservação ex situ e in situ no Brasil e na Venezuela (CARVALHO, 1994).

A peroba-rosa apresenta dificuldades de propagação devido ao fato de a frutificação ser irregular, sendo produzidas grandes quantidades de sementes a cada quatro anos. A coleta de sementes é difícil, devido a grande dimensão das árvores e à germinação irregular (35-70\%). O crescimento lento e a dificuldade no enraizamento de estacas são alguns dos problemas que impedem a reposição dessa espécie, necessitando com urgência de um programa de conservação genética (CARVALHO, 1994).

A propagação de espécies florestais normalmente é via sementes, com exceção de algumas espécies que podem ser multiplicadas via estaquia de material juvenil. Em espécies que apresentam dificuldade de propagação por essas vias, como é o caso da peroba-rosa, a micropropagação é uma ferramenta importante para a multiplicação dessa espécie. Técnicas baseadas na micropropagação de plantas podem ser empregadas com sucesso para a propagação massal de genótipos selecionados, visando à conservação e melhoramento genético (THORPE e KUMAR, 1993).

A micropropagação tem sido ferrramenta útil para muitas espécies florestais de importância econômica ou que se encontram em extinção, por exemplo Pinus pinaster(GOMES et al., 1999), Myracrodruon urundeuva (ANDRADE et al., 2000), Acacia seyal (AL-WASEL, 2000) e Fraxinus angustifolia (TONON et al., 2001), no entanto ainda não existem relatos na literatura sobre a micropropagação da peroba-rosa.

O presente trabalho teve como objetivo o estabelecimento de um protocolo de micropropagação dessa espécie, a partir do cultivo de segmentos nodais de material juvenil.

\section{MATERIAL E MÉTODOS}

Mudas selecionadas de Aspidosperma polyneuron, com dois anos de idade, procedentes do viveiro da Universidade Estadual de Londrina, em Londrina, PR, foram transplantadas em sacos plásticos de $10 \mathrm{~L}$ contendo terra peneirada e mantidas em casa de vegetação pertencente ao Laboratório de Micropropagação Vegetal do Departamento de Fitotecnia e Fitossanitarismo (DFF), no Setor de Ciências Agrárias (SCA) da Universidade Federal do Paraná.

Após um período de adaptação de 15 dias, as mudas foram podadas para estimular a formação de brotações novas, sendo pulverizadas com 0,5 g. $\mathrm{L}^{-1}$ de benomyl (fungicida sistêmico benlate-500) semanalmente. Após três meses, as pulverizações passaram a ser feitas a cada 15 dias.

\subsection{Estabelecimento de culturas assépticas}

Brotações apicais de 2 a $4 \mathrm{~cm}$ de comprimento, contendo uma ou duas folhas, foram coletadas das mudas mantidas na casa de vegetação, desinfestadas com solução de hipoclorito de sódio $(\mathrm{NaOCl}) 0,25 \%$, durante 10 minutos, ou com solução de cloreto de mercúrio $\left(\mathrm{HgCl}_{2}\right)$ 0,05\%, durante 10 minutos. As soluções desinfestantes foram acrescidas de $0,1 \%$ de tween 20 , e as brotações permaneceram em agitação durante a realização dos tratamentos. Em seguida, foram feitas seis lavagens em água deionizada esterilizada. As brotações foram cortadas em sua extremidade basal e inoculadas em tubos de ensaio contendo o meio de cultura WPM(LLOYDe MCCOWN, 1980), suplementado com sacarose $(3 \%)$, mioinositol $(0,01 \%)$, vitaminas do WPM e solidificado com ágar Micromed® $(0,65 \%)$. $\mathrm{O}$ pH foi ajustado em 5,8 antes da autoclavagem do meio de cultura.

\subsection{Indução de brotações multiplas}

Experimento 1 - Brotações apicais estabelecidas in vitro foram cortadas em sua extremidade basal e utilizadas como explantes para indução de brotações múltiplas. O meio de cultura utilizado foi o WPM, suplementado com 6-benzilaminopurina (BAP), cinetina (CIN) e zeatina (ZEA), nas seguintes concentrações: $0 ; 2,2 ; 4,4 ;$ e $8,8 \mu \mathrm{M}$. A avaliação foi feita pela contagem do número de brotações por explante, após quatro semanas, durante o cultivo inicial e nos dois subcultivos subsequientes. 
O delineamento utilizado foi o inteiramente casualizado, em arranjo fatorial $3 \times 4$, com seis repetições e 10 frascos por parcela, possuindo cada frasco uma brotação. As médias foram comparadas pela análise de variância e o efeito das concentrações dos fitorreguladores, por análise de regressão.

Experimento 2 - Brotações apicais estabelecidas in vitro foram utilizadas para induzir a formação de brotações mais alongadas. O meio de cultura utilizado foi o WPM, contendo fitorreguladores: $2,25 \mu \mathrm{M}$ de BAP, ZEA ou CIN, combinados com 1,25 $\mu \mathrm{M}$ de ácido indol-3-butírico (AIB). A avaliação foi feita pela contagem do número de brotações por explante, após quatro semanas, durante o cultivo inicial e nos dois subcultivos subseqüentes.

O delineamento utilizado foi o inteiramente casualizado, com seis repetições e cinco plantas por parcela. As médias foram comparadas pela análise de variância e pelo teste de Tukey.

\subsection{Enraizamento}

Experimento 3 - Brotações individualizadas, pertencentes ao $5^{\circ}$ subcultivo, medindo aproximadamente $2 \mathrm{~cm}$ de comprimento e com a extremidade basal cortada em forma de cunha, foram utilizadas como explantes. O enraizamento foi avaliado com tratamentos de imersão da base $(0,5 \mathrm{~cm})$ das brotações, em soluções de 0 ; 2,5; 5,0; e 10,0 mM de AIB, dissolvidas em etanol 20\%, durante 5 e 15 minutos. Em seguida, os explantes foram colocados em meio de cultura WPM, com a concentração de sais e sacarose reduzida pela metade, durante quatro semanas. A avaliação das porcentagens de enraizamento e a contagem do número de raízes por explante foram feitas após quatro semanas.

O delineamento experimental foi o inteiramente casualizado, em arranjo fatorial 4 x 2, com três repetições com cinco frascos contendo quatro plantas por repetição. As médias foram comparadas pela análise de variância, e o efeito dos níveis de AIB no enraizamento foi comparado por análise de regressão.

Condições de cultivo - As culturas foram mantidas em sala de crescimento com temperatura de $25 \pm 2{ }^{\circ} \mathrm{C}$, fotoperíodo de 16 horas, fornecido por lâmpadas fluorescentes do tipo branca-fria, com densidade de fluxo de fótons fotossinteticamente ativos de $40 \mu \mathrm{mol} \cdot \mathrm{m}^{-2} \cdot \mathrm{s}^{-1}$, no nível das culturas.

\subsection{Transplantio e aclimatização das mudas}

As plantas obtidas in vitro foram transplantadas em bandejas de semeadura de 128 células (cada uma com volume de $30 \mathrm{~cm}^{3}$, área de $3,5 \mathrm{~cm}^{2}$ e altura de 5,5 $\mathrm{cm})$ contendo terra peneirada e plantmax ${ }^{\circledR}$ na proporção de 3:1. As mudas foram mantidas em casa de vegetação, modelo Van der Hoeven.

A avaliação foi feita através da taxa de sobrevivência das mudas após um mês de permanência na casa de vegetação. Após três meses de adaptação e crescimento, as mudas de peroba-rosa foram transplantadas para sacos plásticos contendo o mesmo substrato.

\section{RESULTADOS E DISCUSSÃO}

\subsection{Estabelecimento de culturas assépticas}

$\mathrm{O}$ tratamento de imersão em solução de $\mathrm{NaOCl}$ a $0,25 \%$, durante 10 minutos, foi satisfatório para a desinfestação de brotações apicais de peroba-rosa, tendo em vista que esse tratamento proporcionou $70 \%$ de sobrevivência.

O cloreto de mercúrio foi mais eficiente que o hipoclorito de sódio na desinfestação de brotações apicais de peroba-rosa, possibilitando taxa mais elevada de sobrevivência dos explantes $(84,10 \%)$. Ribas et al. (2003) recomendaram o tratamento de $0,05 \%$ de $\mathrm{HgCl}_{2}$, durante 10 minutos.

A peroba-rosa demonstrou ser sensível às concentrações elevadas das soluções desinfestantes e ao tempo de tratamento, sendo utilizadas concentrações mais reduzidas de $\mathrm{NaOCl}$ e $\mathrm{HgCl}_{2}$ do que as utilizadas em muitas espécies lenhosas, como: Maytenus ilicifolia (PEREIRA et al., 1995), Cercis canadensis (MACKAY et al., 1995), Miscanthus sinensis (NIELSSEN et al., 1993), Hemidesmus indius (PATNAIK e DEBATA, 1996) e Wrightia tomentosa (PUROHIT et al., 1994).

O cloreto de mercúrio, apesar de mais eficiente do que o hipoclorito de sódio na desinfestação de brotações apicais de peroba-rosa, é um produto tóxico e deve ser utilizado com muita cautela (GEORGE, 1993). Esse produto vêm sendo utilizado, com sucesso, para muitas espécies lenhosas que apresentaram sérios problemas de contaminação por microrganismos, como já relatado por Chalupa (1990), Purohit et al. (1994) e Patnaik e Debata (1996).

R. Árvore, Viçosa-MG, v.29, n.4, p.517-524, 2005 


\subsection{Indução de brotações múltiplas}

Experimento 1 - Aanálise de variância do experimento de indução de brotações múltiplas de peroba-rosa, em explantes coletados de mudas de dois anos de idade, mantidas em casa de vegetação, revelou significância estatística para a interação fitorregulador x concentração, no cultivo inicial e nos dois subcultivos avaliados (Teste $\mathrm{F}, \mathrm{P} \leq 0,05)$.

A análise de regressão dos níveis de fitorreguladores indicou que ocorreu aumento nas taxas médias de regeneração de brotações axilares obtidas em meios de cultura suplementados com CIN e ZEA até a concentração de $4,4 \mu \mathrm{M}$, tanto no cultivo inicial quanto também nos dois subcultivos subseqüentes. No entanto, quando BAP foi adicionada ao meio basal, observouse tendência de aumento no número médio de brotações formadas, proporcional ao aumento na concentração empregada, e isso pode ser verificado, principalmente, no primeiro subcultivo (Figura 1).

Dos fitorreguladores testados na peroba-rosa, a ZEA foi mais eficiente na indução e desenvolvimento de brotações axilares, e isso também foi observado em Picea glauca (ELLIS et al.,1991), Acer saccharinum (PREECE et al., 1991) e Acacia senegal (BADJI et al., 1993). Segundo Tamas (1995), a zeatina está entre as citocininas de ocorrência natural mais ativas em promover o crescimento de brotações axilares. As brotações apicais de Acer saccharinum produziram maiores taxas médias de regeneração, com brotações mais longas em meio de cultura suplementado com $10 \mu \mathrm{M}$ de ZEA (PREECE et al., 1991). ZEA e CIN proporcionaram maior alongamento das brotações do que a BAP, como foi observado na peroba-rosa do presente trabalho e documentado em outras espécies (BADJI et al., 1993; FRANÇA et al., 1995; PUROHIT e DAVE, 1996). O alongamento das brotações axilares de peroba-rosa reduziu-se com o aumento de concentração dos fitorreguladores, e isso também foi relatado em outras espécies, como Cercis canadensis (MACKAY et al., 1995) e Carpinus betulus (CHALUPA, 1990).

No presente trabalho, de maneira geral, o uso de BAP ou ZEA resultou nas melhores taxas de indução de brotações múltiplas de peroba-rosa. Resultados semelhantes foram obtidos por França et al. (1995), os quais constataram que BAP foi mais eficiente do que ZEA e 2-iP na proliferação de brotações de Stryphnodendron polyphythum (barbatimão), e as melhores respostas (3,6 brotações por explante) também foram obtidas com concentrações elevadas $(13,3 \mu \mathrm{M})$.

Como foi observado no presente trabalho, as concentrações de BAP entre 4,4 e 8,8 $\mu \mathrm{M}$ também induziram as maiores taxas médias de regeneração de brotações de Halesia carolina. Com 4,4 $\mu \mathrm{M}$ de BAP, as culturas cresceram vigorosamente, produzindo muitas brotações com folhas expandidas. Com $10 \mu \mathrm{M}$ de BAP, aumentouse a taxa média de regeneração, mas as brotações eram menores e possuíam folhas pequenas. Com 2,5 $\mu \mathrm{M}$ de BAP, melhorou-se a qualidade das brotações; no entanto, foram produzidos números moderados de brotações (BRAND e LINEBERGER, 1986). Em outras espécies como Cercis canadensis (MACKAY et al., 1995), Dalbergia latifolia (RAI e CHANDRA, 1989) e Morus australis (PATTNAIK et al.,1996), o número médio de brotações por explante também aumentou com as concentrações crescentes de BAP até 4,4 $\mu \mathrm{M}$.
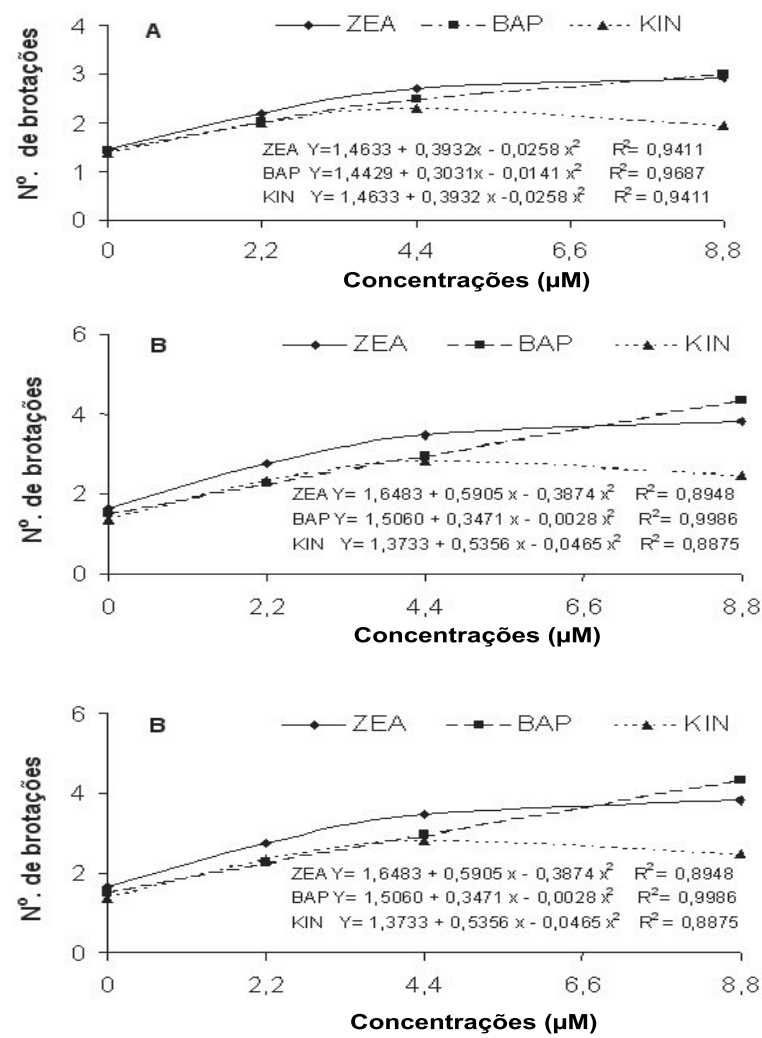

Figura 1 - Efeito dos níveis de fitorreguladores na taxa média de regeneração de brotações de Aspidosperma polyneuron, obtidas no cultivo inicial (A) e no primeiro (B) e segundo (C) subcultivos.

Figure 1 -Growth regulators effects on the average regeneration rate of Aspidosperma polyneuron obtained in the culture initiation (A), first (B) and second subculture (C). 
Resultados semelhantes aos do presente trabalho também foram obtidos com segmentos nodais de Wrightia tomentosa (Apocynaceae) (PUROHIT et al., 1994) e Sterculia urens (PUROHIT e DAVE, 1996), cultivados em meio de cultura MS acrescido de 8,8 $\mu \mathrm{M}$ de BAP. Segundo os primeiros autores, a concentração de $8,8 \mu \mathrm{M}$ de BAP foi necessária durante o estabelecimento da cultura, para a quebra de dominância apical e a indução de brotações. A posterior transferência para meio de cultura com $4,4 \mu \mathrm{M}$ de BAP permitiu a obtenção de brotações mais alongadas. Bennett e Davies Jr. (1986) também obtiveram o maior número médio de brotações regeneradas de segmentos nodais $(6,4)$ de Quercus shumardii cultivadas em meio de cultura WPM, líquido, acrescido de 8,9 $\mu \mathrm{M}$ de BAP.

Tem sido aceito que a CIN promove baixas taxas médias de regeneração de brotações (2-3), ou, então, em algumas espécies esse fitorregulador promove somente o alongamento de brotações, sendo menos eficiente que BAP, como constatado no presente trabalho. Esses resultados foram também confirmados em Eucalyptus globulus (TRINDADE et al., 1990), Morus australis (PATTNAIK et al., 1996) e Cercis canadensis (MACKAY et al., 1995).

Experimento 2 - A análise de variância do número médio de brotações obtidas revelou significância estatística nas combinações de fitorreguladores somente no cultivo inicial (Teste $\mathrm{F}, \mathrm{P} \leq 0,05$ ). $\mathrm{O}$ meio de cultura suplementado com 2,25 $\mu \mathrm{M}$ de CIN e 1,25 $\mu \mathrm{M}$ de AIB resultou em médias de regeneração de brotações superiores às obtidas em meio de cultura contendo $2,25 \mu \mathrm{M}$ de ZEAe 1,25 $\mu \mathrm{M}$ de AIB (Tabela 1). No entanto, no primeiro e no segundo subcultivo, os explantes inoculados em meios de cultura com combinações de fitorreguladores não apresentaram diferenças significativas no número médio de brotações (teste de Tukey, $\mathrm{P} \geq 0,05$ ).
As combinações de fitorreguladores testadas para a peroba-rosa induziram a formação de três a quatro brotações mais alongadas, que mediam entre 1,0 e 3,0 $\mathrm{cm}$ de comprimento, do que as obtidas em meios de cultura suplementados com concentrações mais elevadas de substâncias com atividade citocinínica (5 e $10 \mu \mathrm{M})$, facilitando com isso a transferência para a etapa seguinte de enraizamento. A maioria das brotações regeneradas em meio basal, suplementado com $10 \mu \mathrm{M}$ de BAP, mediam entre 0,5 e $1,0 \mathrm{~cm}$ de comprimento, necessitando de subcultivo para meio de alongamento, antes da indução de raízes. Resultados semelhantes foram obtidos para Cleistanthus collinus, com brotações mais longas induzidas em meios de cultura acrescidos de 2,2 $\mu \mathrm{M}$ de BAP (QURAISHI et al., 1996). Trindade et al. (1990) constataram que níveis baixos de $\operatorname{BAP}(0,4$ e $1,1 \mu \mathrm{M})$, combinados com concentração elevada de auxina (2,5 $\mu \mathrm{M}$ de AIB), estimularam a multiplicação in vitro de Eucalyptus globulus, e o efeito das auxinas provavelmente foi compensar os níveis baixos de citocininas. Declerck e Korban (1994) constataram que, no período de estabelecimento da cultura de Cornus florida, os meios de cultura contendo AIB estimularam um incremento na produção de brotações axilares com os níveis mais elevados de $\operatorname{BAP}(\geq 3,3$ $\mathrm{mM})$. Já, com o emprego de concentrações inferiores ( $\geq 2,2 \mathrm{mM}$ de BAP), a presença de AIB não interferiu na taxa média de regeneração de brotações, assim como observado no presente trabalho. Chalupa (1987) também testou o efeito de diferentes citocininas: CIN, BAP, 2iP e ZEA na multiplicação de Quercus, Castanea, Fraxinus, Betula e Carpinus. Concentrações mais reduzidas de $\operatorname{BAP}(0,88-4,44 \mu \mathrm{M})$ produziram as maiores taxas de multiplicação.

Tabela 1 - Taxa média de regeneração de brotações de Aspidosperma polyneuron obtidas em meio de cultura WPM, suplementado com combinações de fitorreguladores

Table 1 - Mean regeneration rate of Aspidosperma polyneuron shoots obtained in WPM culture medium, supplemented with combinations of growth regulators

\begin{tabular}{lccc}
\hline Fitorreguladores $(\mu \mathrm{M})$ & \multicolumn{3}{c}{ Taxa Média de Regeneração de Brotações } \\
\hline & Cultivo Inicial & Primeiro Subcultivo & Segundo Subcultivo \\
\hline 2,25 ZEA + 1,25 AIB & $2,00 \mathrm{~b}^{1}$ & 2,67 a & 3,67 a \\
2,25 BAP + 1,25 AIB & $2,17 \mathrm{ab}$ & 3,50 a & 3,50 a \\
2,25 CIN + 1,25 AIB & $2,67 \mathrm{a}$ & 3,00 a & 3,33 a \\
\hline
\end{tabular}

${ }^{1}$ Médias com letras diferentes nas colunas diferem significativamente, pelo teste de Tukey (P£0,05). 
Huetteman e Preece (1993) sugeriram o emprego de um meio de cultura primário para indução de taxas elevadas de regeneração de brotações. Posteriormente, os tufos de brotações poderiam ser transferidos para meios de cultura secundários com outras combinações de fitorreguladores. Assim, os explantes de perobarosa podem ser induzidos a regenerar brotações em meio de cultura WPM, contendo $8,8 \mu \mathrm{M}$ de BAP e depois transferidos para meio de cultura contendo $2,25 \mu \mathrm{M}$ de BAPe 1,25 $\mu \mathrm{M}$ de AIB, para promover o alongamento dos tufos de brotações. A preferência pelo BAP, em vez da ZEA, ocorreu devido ao custo mais baixo desse fitorregulador.

\subsection{Enraizamento}

A análise estatística dos tratamentos pulsos de imersão das bases das brotações de peroba-rosa com AIB revelou significância para interação tempo $\mathrm{x}$ concentração (Teste F, P $\leq 0,05$ ).

Os tratamentos de imersão das bases das brotações, durante 15 minutos, resultaram em porcentagens de enraizamento superiores àquelas observadas nos tratamentos realizados durante 5 minutos, quando se utilizaram os níveis de 5 e $10 \mathrm{mM}$ de AIB.

A análise de regressão revelou significância estatística para a porcentagem de enraizamento das brotações obtida após os tratamentos com AIB, observando-se aumento nessa porcentagem, proporcional ao aumento da concentração de AIB (Figura 2). O tempo de 15 minutos aumentou a porcentagem de enraizamento até a concentração de $10 \mathrm{mM}$ de AIB, enquanto para o tempo de 5 minutos ocorreu maior aumento na porcentagem de enraizamento até $5 \mathrm{mM}$ de AIB, seguido de uma tendência de estabilização da porcentagem de enraizamento nas concentrações mais elevadas. Bennett e Davies Jr. (1986) obtiveram resultados semelhantes aos do presente trabalho, em resposta a níveis mais reduzidos de AIB em brotações de Quercus shumardii.

\subsection{Transplantio e aclimatização de mudas}

Apesar de as brotações de peroba-rosa apresentarem apenas uma ou duas raízes, as mudas plantadas exibiram taxas de sobrevivência superiores a 90\%. Logo após o transplantio, as mudas formaram folhas novas e reiniciaram o crescimento. Depois de 8 a 12 semanas de permanência em bandejas de semeadura, as mudas possuíam raízes bem desenvolvidas e foram transplantadas para sacos plásticos, permanecendo ainda em casa de vegetação.

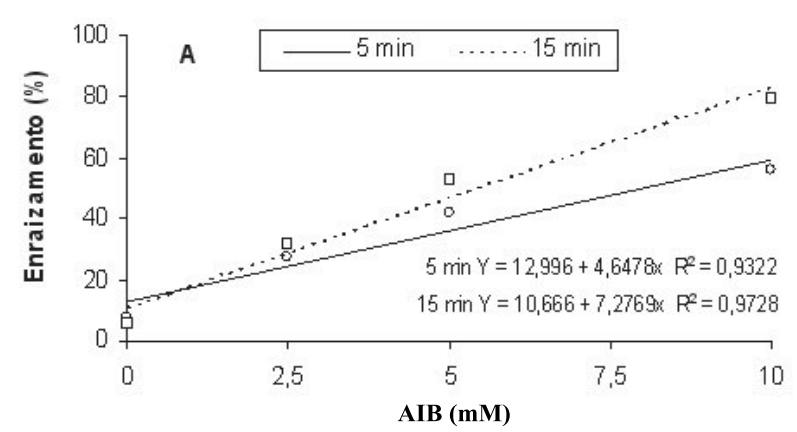

Figura 2 - Efeito dos tratamentos com soluções de AIB no enraizamento (\%) de brotações de Aspidosperma polyneuron.

Figure 2 - Treatment effect with IBA solution on rooting (\%) of Aspidosperma polyneuron shoots.

Com base nos resultados obtidos, pôde-se estabelecer um protocolo de regeneração in vitro de peroba-rosa pela micropropagação. A utilização desse protocolo permite uma previsão do número de mudas regeneradas in vitro, após um período de seis meses, considerando-se que a eficiência de cada etapa seja de 70\%. Assim, partindo-se de 100 brotações apicais, a indução de brotações múltiplas ocorre em meio de cultura WPM, suplementado com $8,8 \mu \mathrm{M}$ de BAP, resultando em taxas médias de regeneração de $3 ; 4$; e 4,5 brotações, respectivamente para o cultivo inicial e dois subcultivos. O estágio de alongamento ocorre em meio de cultura WPM, acrescido de 2,25 $\mu \mathrm{M}$ de BAP e 1,25 $\mu \mathrm{M}$ de AIB, durante um mês, com uma taxa média de regeneração de 3,5 brotações. A indução de raízes ocorre em resposta a tratamento- pulso com solução de $10 \mathrm{mM}$ de AIB, durante 15 minutos, com $70 \%$ de enraizamento. Finalmente, o transplantio e aclimatização podem ser efetuados em casa de vegetação com $70 \%$ de sobrevivência. Em decorrência, poderia ser prevista a obtenção de 1.667 mudas de peroba-rosa após um período de seis meses.

\section{CONCLUSÕES}

No presente trabalho foi estabelecido um protocolo de regeneração de mudas de peroba-rosa a partir de material juvenil. De maneira geral, os fitorreguladores testados foram eficientes para promover a quebra de dominância apical e o desenvolvimento de brotações axilares de peroba-rosa. BAP e ZEA proporcionam as maiores taxas médias de regeneração, nos níveis entre 4,4 e $8,8 \mu \mathrm{M}$, constatando-se que o número de brotações 
aumenta com o número de subcultivos. Brotações mais alongadas ocorrem como resposta ao emprego de concentrações mais reduzidas de ZEA e CIN. A aclimatização de plantas de peroba-rosa obtidas in vitro foi possível, tornando viável a micropropagação dessa espécie.

\section{AGRADECIMENTOS}

Ao Dr. Edilson B. de Oliveira, pela orientação da análise estatística; e a CAPES, pela concessão da bolsa de estudos.

\section{REFERÊNCIAS BIBLIOGRÁFICAS}

AL-WASEL, A. S. Micropropagation of Acacia seyal Del. in vitro. Journal of Arid

Environments, v. 46, p. 425-431, 2000.

ANDRADE, M. W. et al. Micropropagação de aroeira (Myracrodruon urundeuva Fr. All.). Ciência Agrotécnica, v. 24, n.1, p. 174-180, 2000.

BADJI, S. et al. In vitro propagation of the gum arabic tree (Acacia senegal (L.) Willd.). 1Developing a rapid method for producing plants. Plant Cell Report, v.12, p. 629-633, 1993.

BENNETT, L. K.; DAVIES JR., F. T. In Vitro Propagation of Quercus shumardii seedlings. Hortscience, v.21, n.4, p. 1045-1047, 1986.

BRAND, M. H.; LINEBERGER, R. D. In vitro propagation of Halesia carolina $\mathrm{L}$. and the influence of explantation time on initial shoot proliferation. Plant Cell, Tissue Organ Culture, v. 7, n. 2, p. 103-113, 1986.

CARVALHO, P. E. R. Espécies florestais brasileiras: recomendações silviculturais, potencialidades e uso da madeira. Colombo: EMBRAPA-CNPF, 1994. p. 79-84.

CHALUPA, V. European hardwoods. In: BONGA, J. M.; DURZAN, D. J. Cell and tissue culture in forestry. Dordrecht: Martinus Nijhoff, 1987. p. 224-246.

CHALUPA, V. Micropropagation of Hornbeam (Carpinus betulus L.) and Ash. (Fraxinus excelsior L.). Biologia Plantarum, v. 32, n.5, p. 332-338, 1990.
DECLERCK, V.; KORBAN, S. S. Effects of source macronutrients and plant growth regulator concentrations on shoot proliferation of Cornus florida. Plant Cell Tissue Organ Culture, v.38, n.1, p.57-60, 1994.

ELLIS, D. D. et al. A comparison of BA, zeatin and thidiazuron for adventitious bud formation from Picea glauca embryos and epicotyl explants. Plant Cell Tissue Organ Culture, v. 27, p. 281-287, 1991.

FRANÇA, S. C. et al. Micropropagation of Stryphnodendron polyphythum (Barbatimão). Plant Cell Tissue Organ Culture, v. 42, p. 291-293, 1995.

GEORGE, E. F. Plant propagation by tissue culture: the technology. Great Britain: Exegetics Limited, 1993. v. 1574 p.

GOMES, F. et al. Micropropagação do pinheiro bravo (Pinus pinaster Aiton). Silvia Lusitana, v. 7, n.2, p. 139-152, 1999.

HATSCHBACH, G. G.; ZILLER, S. R. Lista vermelha de plantas ameaçadas de extinção no Estado de Paraná. Curitiba: SEMA/GTZ, 1995. 139 p.

HUETTEMAN, C. A.; PREECE, J. E. Thidiazuron: a potent cytokinin for woody plant tissue culture. Plant Cell Tissue Organ Culture, v. 33, p. 105-109, 1993.

LLOYD, G.; MCCOWN, B. Commercially feasible micropropagation of mountain laurel Kalmia latifolia by use of shoot-tip culture.

Combined Proceedings of

International Plant Propagation Society, v.30,p.421-427, 1980.

MACKAY, W. A.; TIPTON, J. L.; THOMPSON, G.A. Micropropagation of Mexican redbud, Cercis canadensis var. mexicana. Plant Cell Tissue Organ Culture, v. 43, p. 295-299, 1995.

NIELSEN, J. M.; BRANDT, K.; HANSEN, J. Longterm effects of thidiazuron are intermediate between benzyladenine, kinetin or isopentenyladenine in Miscanthus sinensis.

Plant Cell Tissue Organ Culture, v. 35, p. 173-179, 1993.

R. Árvore, Viçosa-MG, v.29, n.4, p.517-524, 2005 
PATNAIK, J.; DEBATA, B. K. Micropropagation of Hemidesmus indicus (L.) R. Br. through axillary bud culture. Plant Cell Report, v. 15, p. 427-430, 1996.

PATTNAIK, S. K.; SAHOO, Y.; CHAND, P. K. Micropropagation of a fruit tree, Morus australis Poir. syn. M. acidosa Griff. Plant Cell Report, v. 15, p.841-845, 1996.

PEREIRA, A. M. S. et al. Effect of phytoregulators and physiological characteristics of the explants on micropropagation of Maytenus ilicifolia. Plant Cell Tissue Organ Culture, v. 42, p. 295-297, 1995.

PREECE, J. E.; HUETTEMAN, C. A.; ASHBY, W. C. Micro- and cutting propagation of silver maple I. Results with adult and juvenile propagules. Journal American Society Horticulture Science, v. 116, n. 1, p. 142$148,1991$.

PUROHIT, S. D.; DAVE, A. Micropropagation of Sterculia urens Roxb.- an endangered tree species. Plant Cell Report, v. 15, p. 704706, 1996.

PUROHIT, S. D. et al. In vitro propagation of an adult tree Wrightia tomentosa through enhanced axillary branching. Plant Science, v. 103, p. 67-72, 1994.
QURAISHI, A .; KOCHE, V.; MISHRA, S. K. In vitro micropropagation from nodal segments of Cleistanthus collinus. Plant Cell Tissue Organ Culture, v.45, p. 87-91, 1996.

RAI, V. R. ; CHANDRA, K. S .J.

Micropropagation of indian rosewood by tissue culture. Annual Botany, v. 64, p. 43-46, 1989.

RIBAS, L. L. F.; ZANETTE, F.; KULCHETSCKI, L.; GUERRA, M. P. Estabelecimento de culturas assépticas de Aspidosperma polyneuron.

Ciência Florestal, v. 13, n.1, p.115-122, 2003.

TAMAS, I A. Hormonal regulation of apical dominance. In: DAVIES, P. J. (Ed.) Plant Hormones. Dordrecht: Kluwer Academic, 1995. p. 572-597.

THORPE, T. A.; KUMAR, P. P. Cellular control of morphogenesis. In: AHUJA, M. R. (Ed.)

Micropropagation of woody plants. Netherlands: Kluwer Academic, 1993. p. 11-29.

TONON, G.; CAPUANA, M.; DIMARCO, A. Plant regeneration of Fraxinus angustifolia by in vitro shoot organogenesis. Scientia Horticulturae, v. 87, p. 291-301, 2001.

TRINDADE, H. et al. The role of cytokinin in rapid multiplication of shoots of Eucalyptus globulus grown in vitro. Australian Forestry, v. 53, n. 3, p. 221-223, 1990. 